\title{
İletişimin Dijitalleşmesi: Pandemi (COVID-19) ve Enformasyon Teknolojileri
}

Nurat KARA, Hatay Mustafa Kemal Üniversitesi, Fen Bilimleri Enstitüsü, Enformatik Anabilim Dalı, Doktora Öğrencisi, nkara@mku.edu.tr, (D) 0000-0001-9753-1593

Mehmet KARANFILOĞLU, Hatay Mustafa Kemal Üniversitesi, İletişim Fakültesi, Halkla İlişkiler ve Tanıtım Bölümü, Dr. Arş. Gör., mehmetktr@mku.edu.tr, (D) 0000-0002-4895-4220

$\ddot{O Z Z}$

Dünyada bilginin üretimi ve tüketimi konusunda tartı̧malar artarak ileri bir noktaya doğru gitmektedir. Bilginin üretiminde kullanılan enformasyon teknolojileri de gün be gün daha çok gelişmekte ve çeşitlenmektedir. Enformasyon teknolojileri günümüz yaşam koşullarının oluşmasında önemli bir role sahiptir. Bu teknolojilerin giderek yayginlaşması pek çok işin ve yaşamsal sürecin iyileşmesine yardımcı olmaktadır. Bu sayede birçok iş sürecinin hız, zaman ve mekansal bağlamda daha iyiye doğru gittiğgi görülmektedir. Öte yandan yeni tip koronavirüs (COVID-19) Çin'den tüm dünyaya yayılarak küresel çapta bir pandemiye dönüşmüştür. Aralık ayından günümüze halen devam etmekte olan pandemi süreci pek çok olumsuz durumu da beraberinde getirmiştir. İlk vakanın ortaya çıktı̆̆ $l$ Çin'de ise vaka artış hizı durma noktasina gelmiş, normalleşme sürecine girilmiş ve bu süreç devam etmektedir. Çin'de bu durumun yaşanmasında kuşkusuz ki enformasyon teknolojilerinin katkısı yadsınamaz bir gerçektir. Telefon uygulamaları, 5G teknolojisi, bulut bilişim, algoritmalar, yapay zeka, büyük veri, nesnelerin interneti gibi teknolojiler pandemi sürecinde sıkça kullanılan enformasyon teknolojileri olarak karşımıza çıkmaktadır. Bu çalışma ile Çin örneğinde bu durumun incelemesi yapılarak enformasyon teknolojilerinin pandemi sürecindeki önemi yapılan literatür ve çeşitli kaynak taraması ile ortaya konmaya çalışılmaktadır.

Anahtar : $\quad$ Koronavirüs, Pandemi, Enformasyon Teknolojileri, Dijitalleşme, COVID-19

Kelimeler

\section{Digitalization of Communication: The Pandemic (COVID-19) and Information Technologies}

\begin{abstract}
Discussions about the production and consumption of information in the world are increasingly advancing. Information technologies used in the production of knowledge are also developing and diversifying day by day. Information technologies play a crucial role in the formation of today's living conditions. The widespread use of these technologies is helping many businesses and life processes improve. In this way, many business processes are getting better in terms of speed, time, and spatial. On the other hand, the new type of coronavirus (COVID-19) has spread from China to the whole world and has turned into a global pandemic. The pandemic process, which has been continuing since December, has brought many negative situations
\end{abstract}


with it. In China, where the first case occurred, the rate of increase in cases came to a halt, and the normalization process continues. Undoubtedly, the contribution of information technologies to experiencing this situation in China is an undeniable fact. Technologies such as phone applications, 5G technology, cloud computing, algorithms, artificial intelligence, big data, and the internet of things appear as information technology opportunities that are frequently used in the pandemic process. In this study, we examined the importance of information technologies in the pandemic through the literature and other sources by analyzing the case of China.

\section{Keywords : $\quad$ Coronavirus, Pandemic, Information Technologies, Digitalization, COVID-19 GİRiş}

Enformasyon teknolojilerinin gelişmesiyle birlikte dünya sürekli bir değişim ve gelişimin içerisinde hızla yeni koşullara doğru ilerlemektedir. Bir yandan teknolojilerin sayısındaki artışla, her gün pek çok yeni yetenekteki teknolojinin hayatımıza girmesi işlerimizi kolaylaştırırken diğer yandan yaşanan doğal afetler, salgın hastalıklar gibi olumsuz sonuçları olan olaylar da kitleleri kötü yönde etkileyebilmektedir. 2019'un son aylarında ortaya çıan ve hızla dünya çapında yayılım gösteren yeni tür koronavirüs (COVID-19 ) pandemisi de tüm insanlığı olumsuz yönde etkilemiş ve etkilemeye de devam etmektedir.

$\mathrm{Bu}$ olumsuz koşullarda pek çok yönden kısıtlanarak yaşamak zorunda kalan bireyler, geçmişteki alışkanlıklarını değiştirmek ve "yeni normal" denilen yeni davranış biçimlerini benimsemek zorunda kalmıştır. Örneğin; merhabalaşmak için yapılan toklalaşma eylemi, fiziksel temas gerektirdiğinden ve virusün birinden diğerine aktarımına neden olduğundan yerini değişik şekillerde temas içermeyen merhabalaşmalara bırakmıştır. Yalnızca, doğrudan bir şekilde, insandan insana bulaşmayan temas edilen yüzeyler aracılığı ile de bulaşabilen covid-19 virüsü, temizliğe ve temizlik malzemelerine olan ilgiyi de artırmıştır. Bireylerin fiziksel olarak marketlerden alışveriş yapmak yerine internet üzerinden yüzde 171 oranında daha fazla satın alma davranışı gerçekleştirdiği, kişisel bakım için yüzde 171 ve ev bakım ürünleri için de yüzde 162 oranında daha fazla ürün satın aldıkları ortaya çıkmıştır (Kişin, 2020).

Alışkanlıkların değişmek zorunda kaldığı bir dönem olarak karşımıza çıkan COVID-19 pandemi süreci bireyleri her alanda daha çok dikkatli olmak konusunda zorlamaktadır. Eski alışkanlıkları daha farklı şekillerde gerçekleştirmek zorunda kaldığımız bu süreçte enformasyon teknolojilerinin sunmuş olduğu yeni olanaklar tüm süreçleri hiç olmadığı kadar hızlı bir şekilde dijitalleştirebilmemize olanak tanımaktadır. Fiziksel olarak temas içinde olmadan cep telefonları, bilgisayarlar ve tabletleri kullanarak internet üzerinden tüm enformasyon süreçleri hız kesmeksizin devam edebilmektdir. Bazı görüşlere göre pandemi ile birlikte dijitalleşme sürecinin hız kazandığı düşünülmektedir (Süleymanlı, 2020). 
Buradan hareketle, bu çalışma enformasyon teknolojilerinin getirdiği olanakların iletişimsel süreçleri nasıl dönüştürdügünü COVID-19 bağlamında irdelemeyi amaçlamaktadır. Bu doğrultuda çalışmada, COVID-19 pandemi sürecinde iletişimin enformasyon teknolojilerinden nasıl ve ne yönde etkilendiği kaynak ve literatür taramasıyla ortaya konmaya çalışılmıştır.

\section{Kaynak Araştırması}

\subsection{Enformasyon Teknolojileri}

Teknolojinin gelişimi kendini enformasyonun dört aşaması; enformasyonunn elde edilmesi, saklanması, işlenmesi ve aktarılması üzerinden mesafe, hız, miktar ve güvenilirlik şeklinde göstermektedir (Akıncı-Vural, 2005, s. 126). Gelişim arttıkça enformasyonun hızı, miktarı ve güvenilirliği artmaktadır. Ayrıca bu teknolojilerdeki gelişim iki nokta arasındaki mesafeyi de önemli ölçüde kısaltmaktadır. Kablolu bir şekilde sağlanan iletişimden kablosuz olanaklara doğru geçtiğimiz bir dönemde veri aktarım hızındaki mesafenin önemsizliği bizi her an her yerde olabilme konusunda daha da yetenekli hale getirmektedir. Dolayısıla enformasyon kavramı teknolojik imkanların artmasıyla birlikte daha da önemli hale gelmektedir diyebiliriz.

Enformasyon kavramı veri ve bilgi kavramları ile doğrudan ilişkilidir. Bu ilişkiyi anlamak üzere bu kavramlara ve anlam ayrımlarına bakmak gerekmektedir. Literatürde bu kavramların anlam kargaşası yaratacak şekilde birbiri yerine -özellikle bilgi ve enformasyon kavramlarının- kullanıldığına dair görüşler bulunmaktadır (İpe, 2003). Bu kavramların arasındaki anlam ayrımını belirten yazarlar olduğu gibi (Davenport \& Prusak., 2001; Pemberton, 1998), aynı anlama gelecek şekilde kullananlar (Stewart, 1997) da bulunmaktadır. Veri, enformasyon ve bilgi kavramlarına genel olarak bakacak olursak veri; nesneleri, durumları ve özellikleri resmeden unsurları içerir (Ackoff, 1996). Verilerin işlenmesi; özetlenmesi, düzenlenmesi gibi işlemler onu enformasyona dönüştürmektedir (Kalseth \& Cummings, 2001). Enformasyon, verinin işlenmesi ve aktarılaması olarak da ele alınabilmektedir (Ural, 2012, s. 537). Başka bir görüşe göre de anlam kazanmış veya yüklenmiş veri şeklinde tanımlanmaktadır (Yalçın, 2017, s. 95; Dervişoğlu, 2004). Bilgi ise enformasyona dönüşmüş verilerin insan zihindeki yansımasıdır. Gelen enformasyonun beyin tarafından algılanarak işlenmesi bilgi olmaktadır (Akgün \& Keskin, 2003, s. 176).

Enformasyon teknolojileri (Information Technologies) denildiğinde akla donanım, yazılım ve ağlardan oluşan teknolojiler gelmektedir. Bu teknolojiler fiziksel olabildikleri gibi fiziksel olmayan olanaklardan da oluşmaktadır (Acar, 2008, s. 54-55). Fiziksel olan teknolojiler; bilgisayarlar, çevre birimleri, telekomünikasyon sistemleri, yazıcılar iken fiziksel olmayan teknolojiler de; siber güvenlik programları, bulut sistem arayüzleri, akıllı telefon uygulamaları gibi daha yazılımsal ürünlerden oluşmaktadır. Bu teknolojiler dünya çapında pek çok farklı sektörde kullanılmakta; iletişimin ve haberleşmenin yeni "temel" araçları arasında yer alabilecek derecede büyük bir öneme sahip olmaktadır. 


\subsection{Enformasyon Teknolojilerinin COVID-19 Pandemi Sürecindeki Önemi}

İlk olarak Çin Halk Cumhuriyeti'nin (Kısaca: Çin) Vuhan Eyaleti'nde 2019'un sonlarında görülmeye başlanan yeni tip koronavirüs vakaları 13 Ocak 2020'de resmi olarak tanımlanmıştır. Bir grup hasta üzerinde yapılan araştırmalar sonucunda hastaların solunum yolu belirletileri (ateş, nefes darlığı, ishal, öksürük...) gösterdikleri tespit edilmiştir (SağlıkBakanlığı, 2020). Koronavirüs; deve, kedi, yarasa gibi hayvanlarda bulunabilen virüslerdendir. Hayvandan insana bulaşabilmekte ve daha sonra insandan insana bulaşabilen daha önce de örnekleri bulunan büyük bir virüs ailesidir. Bilinen bazı türleri arasında MERS-CoV, SARSCoV ve 2019-nCoV sayılabilmektedir (Türk-Eczacıları-Birliği, 2020).

Kısa sürede dünya çapında yayılım gösteren COVID-19, ülkemizde de ilk vakalarını resmi sonuçlara göre 10 Mart 2020'de göstermeye başlamış (AA, 2020) ve yine kısa sürede tüm ülkeye yayılmıştır. Bunun bir sonucu olarak ülke geneli pek çok sektör çalışmaya ara vermek durumunda kalmış ve belirli sürelerle sokağa çıkma yasağı konularak tüm ülkede fiziksel ulaşım ve etkileşim durma noktasına gelmiştir. Ancak sürecin belirsiz oluşu, tedavi ve/veya önlem amaçlı bir aşının henüz geliştirilememiş olması gibi nedenlerle pek çok sektörde uzaktan, dijital yöntemlerle süreç atlatılmaya çalışılmıştır. Enformasyon teknolojilerin çeşitlenmesi ve gelişmesi sayesinde zaten başlamış olan dijital dönüşüm pandemi süreci ile birlikte ivme kazanarak (Develi, 2020) daha çok "uzaktan/evden" diye başlıklandırılan iş yapış süreçleri yaygınlaşmıştır. Bu noktada enformasyon teknolojilerinin sunduğu olanaklar ön plana çıkmaktadır. Benzer şekilde yaşanan önceki salgın hastalıklarda enformasyon teknolojilerindeki sinırlılıklar salgınla başetme durumunu daha güç hale getirmiştir. 1918 ile 1920 arasında yaşanan İspanyol Gribi salgını da o dönemki dünya nüfusunun üçte birini hasta etmiş ve tahminen 20-50 milyon insanın ölümüne sebebiyet vermiştir (Duarte, 2020). Kuşkusuz bu neticede o dönemki sosyo-ekonomik koşullar, politik olaylar, tıbbi imkanlar gibi unsurlar da etkili olmuştur. Bununla birlikte enformasyon teknolojilerinde gelişmişlik seviyesi ve dönemsel imkanlar da salgının algınlanması, bilinmesi ve önlemlerin uygulanabilmesinde etkili olmuştur. Günümüzdeki olanaklar sayesinde Çin' de tespit edilen ilk vakaların haberi ilk andan itibaren tüm dünyaya yayılmış, ülkeler çeşitli önlemleri bu sayede alabilmiştir. Çin'deki ilk vakanın tespiti de yine enformasyon teknolojilerinin katkısıyla gündeme gelebilmiştir. Çin'in Vuhan şehrinde çalışan Dr. Li Wenliang'ın aynı şikayetleri paylaşan bir kaç hastasındaki durumu Çin'in Whatsapp'ı denilebilecek telefon mesajlaşma uygulaması olan WeChat üzerinden arkadaş grubuyla paylaşmasıyla durum ortaya çıkmış, medyaya yansımıştır (AA, 2020).

Özellikle sosyal medya üzerinden yapılan paylaşımların anında viral bir şekilde yayılması virüs ile ilgili pek çok bilginin herkesçe öğrenilmesine olanak sağlamıştır. Aynı zamanda, özellikle sosyal medya üzerinde, COVID-19 ile ilgili yalan bilgilerin de üretilmesi ve yayılması da gerçekleşmiştir (Aydın, 2020, s. 77). Pek çok yalan bilginin salgının neden olduğu panik ve 
belirsizlik durumu sebebiyle sorgulanmadan paylaşılabildiği görülmüştür (Aydın, 2020, s. 77). Ancak, yine enformasyon teknolojilerinin sunduğu diğer imkanlarla birlikte bu bilgilerin teyit edilmesi ve/veya doğrulanması da mümkün olabilmektedir. Böylece yanlış bilgilerin doğru bilgilerle yer değiştirerek benzer şekilde yayılması da mümkün olabilmektedir.

Enformasyon teknolojilerinin pandemi sürecinde faydalı ve yaratıcı çözüm üretme, özellikle bulaşma riskinin azaltılması, yayılma hızının önlenmesi noktasında da birçok faydası bulunmaktadır. Pandemi sürecinde iletişim imkanlarının hiç olmadığı kadar artması devletlerin yayılımın azaltılması çabasında önemli katkıları beraberinde getirmiştir. Örneğin; ülkemizde Sağlık Bakanlığı'nın resmi web sitesi üzerinde COVID-19 ile ilgili olarak pek çok rapor, broşür, kayıt, afiş gibi bilgilendirici materyaller hazırlanmış, kamu ve özel sektörün kullanımına sunulmuştur. Yalnızca birkaç adımda internet üzerinden ve yazıcı (printer) aracılığı ile bu bilgileri edinmek ve kurum içinde uygulamak kolayca mümkün olabilmektedir.

Öte yandan enformasyon teknolojileri sayesinde tahminleme yapabilmek, karar alma noktasında bu teknolojileri kullanmak da pandemi sürecinde çok önemli hale gelmiştir. Tahminleme programları, yapay zeka, büyük veri (big data) analizleri ile önceden COVID19'un yayılımı ile ilgili toplamda kaç kişinin hastalanabileceği, ölebileceği, ne kadar tıbbi malzeme gerekebileceği gibi soruların cevapları alınabilmekte ve bu sayede önlemlerin alınabilmesi, tedarik noktasında nelerin gerekebileceğinin önceden öğrenilmesi olanaklı hale gelmektedir. 
Dr. Fahrettin Koca @ @drfahrettinkoca·3h

Bugün 1.517 hastamız daha var. İyileşenlerin sayısı 1.000'den fazla. Aktif hasta sayımız da ağır hasta sayımız da artmaya devam ediyor. Bugün 36 CAN daha kaybettik. Hasta sayısını da can kayıplarını da azaltacak olan tedbirlere uyumdur. covid19.saglik.gov.tr

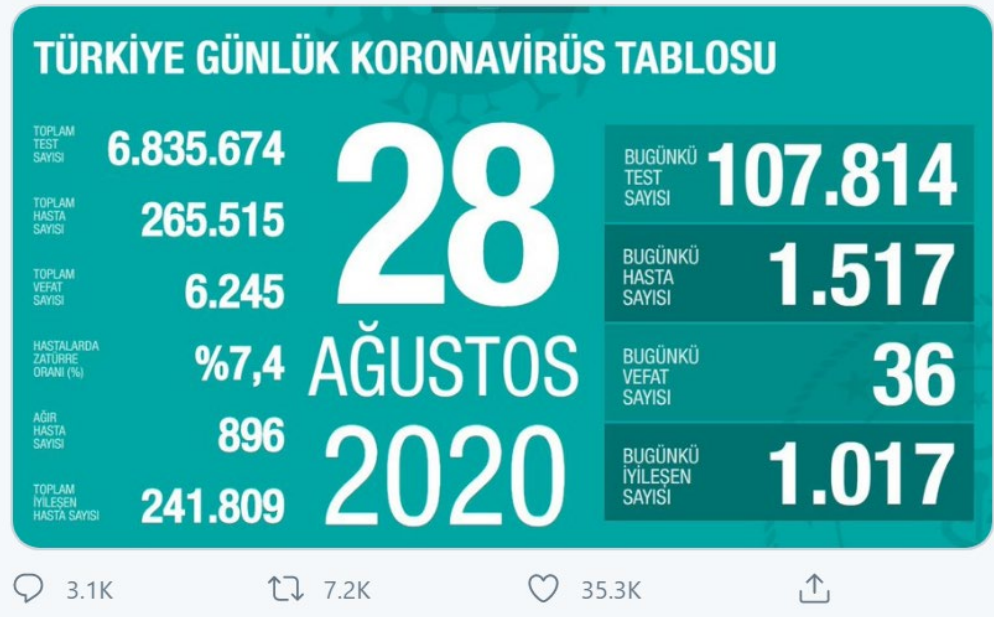

Şekil 1. T.C. Sağlık Bakanı Dr. Fahrettin Koca Twitter Hesabı Paylaşımı
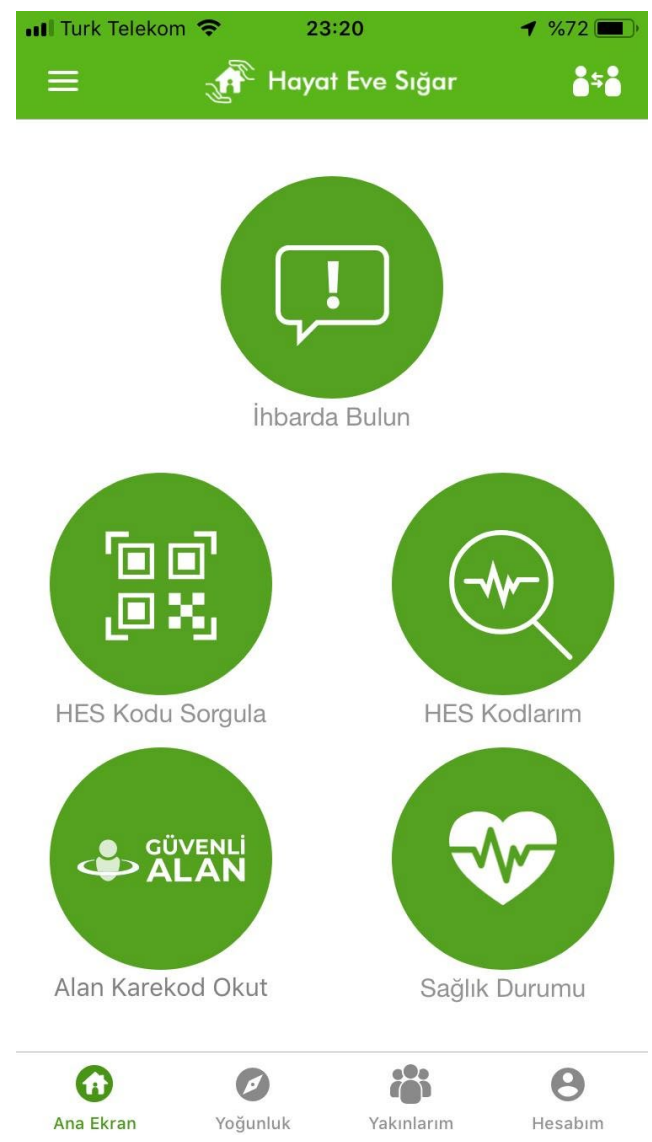

Şekil 2. "Hayat Eve Siğar-HES” Uygulaması 
Ülkemizde buna yönelik olarak Sağlık Bakanlığı tarafından, bizzat T.C. Sağlık Bakanı Dr. Fahrettin Koca'nın twitter hesabı üzerinden günlük olarak vakalara yönelik bilgiler paylaşılmaktadır (bkz. Şekil 1). Aynı zamanda Koca'nın bu hesap üzerinden uyarıcı, önleyici ve diğer dikkat çekici mesajlarını gün içinde paylaşarak virüsün yayılmasını önlemeye yönelik iletilerini paylaştığı da görülmektedir. Öte yandan yine Sağlık Bakanlığı tarafından oluşturulan Hayat Eve Sığar (HES) uygulamasını cep telefonları üzerinden indirmek ve uygulama üzerinden ihbarda bulunmak, HES kodu almak ve kod sorgulamak, bulunulan alanın güvenli olup olmadığının sorgulanması ve sağlık durumunu online olarak kontrol etmek mümkündür. Hesap hem kişisel hem de yakınları kontrol altında tutabilecek özelliklere sahip olmakla birlikte ülke geneli ve şehir merkezli yoğunluk haritaları da barındırmaktadır (bk. Şekil 2). Tüm bu çalışmaların enformasyon teknolojilerinin sağladığı olanaklarla yapıldığı düşünüldüğünde, COVID-19 pandemisi sürecinde enformasyon teknolojillerinin ne denli önemli bir konumda olduğu anlaşılmaktadır.

\section{COVID-19 Pandemi ile Savaşmada Enformasyon Teknolojilerinin Kullanımına Yönelik Bulgular: Çin Örneği}

Aralık ayında Çin'de ilk vakaların görülmeye başlandığı ilk günden bu yana küresel çapta pek çok kurum (Dünya Sağlık Örgütü, Dünya Ekonomi Forumu, Türkiye Sağlık Bakanlığı, Deloitte...) yeni tip koronavirüs ile ilgili olarak araştırma yapmış ve çarpıcı verileri ortaya koymuştur. İlk veriler çeşitli ülkelerde ve bölgelerde görülen toplam onaylanmış vaka ve ölen kişi sayılarına yönelik olarak gerçekleşmiştir. Dünya Sağlık Örgütü'ne göre 28 Ağustos 2020 itibariyle dünya genelinde 281.581 kişi yeni vaka, 24.299 .923 kişi onaylanmış vaka, 827,730 adet ölüm gerçekleşmiştir (WHO, 2020).

Tablo 1. Bölgelere Göre Vaka-Ölüm Sayıları Dağılımı (Mart-Ağustos 2020) (WHO, 2020)

\begin{tabular}{|c|c|c|}
\hline Bölge & $\begin{array}{c}\text { Onaylanmıs } \\
\text { Vaka Sayıs }\end{array}$ & Vefat Sayısı \\
\hline $\begin{array}{c}\text { Amerika (Güney- } \\
\text { Kuzey) }\end{array}$ & 12.869 .643 & 454.818 \\
\hline Avrupa & 4.139 .141 & 218.461 \\
\hline Güney-Doğu Asya & 3.905 .060 & 73.097 \\
\hline Doğu Akdeniz & 1.878 .490 & 49.883 \\
\hline Afrika & 1.029 .787 & 21.151 \\
\hline Batı Pasifik & 477.061 & 10.307 \\
\hline Toplam & 24.299 .182 & 827.717 \\
\hline
\end{tabular}


Tablo 1'de görülebileceği üzere dünya üzerinde 24 milyon civarında onaylanmış vaka, 800 bin civarında ise COVID-19 kaynaklı ölüm kaydı bulunmaktadır. İlk vakanın ortaya çıktığı Çin'e bakıldığında ise 85 bin civarında toplam vaka sayısı, 4 bin 600 civarında da ölüm kaydı, 80 bin civarında ise iyileşen kaydı bulunmaktadır (Worldometer, 2020). Ülkemizde ise 265 bin 500 civarı vaka, 6 bin 200 civarı ölüm kaydı, 241 bin 800 civarı da iyileşen kaydı bulunmaktadır (Worldometer, 2020). Bu kayıtlara bakıldığında yine enformasyon teknolojilerinin sunduğu imkanların yardımı ile bu veriler toplanabilmektedir. Çeşitli yöntemlerin ve cihazların yardımı ile yapılan koronavirüs testi sonuçları ilgili kurum ve kuruluşlarla internet üzerinden paylaşılmakta ve toplanan verilerle bu analizler yapılabilmektedir.

Diğer taraftan sağlık alanında yapılan çalışmalar, sosyal mesafe, izolasyon, kısıtlama çalışmaları gibi uygulamalarla birlikte COVID-19 ile savaşmada büyük veri, nesnelerin interneti, yapay zeka, bulut bilişim, siber fiziksel sistemler, artırılmış gerçeklik gibi teknolojilerin kullanıldığı bilinmektedir. Bu teknolojilerin yardımı ile gerçekleştirilen pek çok proje hız, zaman ve mekan bağlamında muazzam ölçüde gerçekleştirebilmeyi sağlamaktadır. (anlamadım) Çin merkezi televizyonundan alınan habere göre, COVID-19 ile mücadele için Pekin'de yapılmak istenen bin yataklı hastane projesi (Huoshenshan Hastanesi) bu teknolojilerin de yardımıyla on günde tamamlanabilmiştir (AA, 2020).

Buradan hareketle Çin'de COVID-19'le mücadelede kullanılan teknolojilere bakmakta fayda vardır. Yapılan kaynak taramasına yönelik sonuçlar aşağıda paylaşılamaktadır. Bu bulgulara göre kullanılan teknolojiler şu şekilde sıralanabilmektedir (Deloitte-Türkiye, 2020):

- Algoritmalar,

- Blockchain,

- Endüstri 4.0,

- Bulut Bilişim,

- Akılli Ses Tarama Sistemi,

- Akıllı Görüntü Okuma Sistemi,

- 5G Teknolojisi,

- 5G Devriye Robotları,

- Drone Teknolojisi,

- Akıllı Uygulamalar,

- Uzaktan Eğitim/Çalışma.

Deloitte Türkiye'nin hazırladığı raporda yer alan bilgilere göre Çin'de kullanılan bu teknolojilerin COVID-19'le mücadelede faydası oldukça etkili olduğu görülmektedir. Çünkü bu sayede Çin'de hızla artan vakalarda artış neredeyse durma noktasına gelebilmiştir (AA, 2020). Elbette ki bu durumda Çin'de uygulanan sıkıyönetimin de oldukça büyük bir etkisi olduğu yadsınamaz ancak sıkıyönetim kararının alınmasına neden olan durumu analiz 
edebilmeyi de sağlayan yine enformasyon teknolojileri olarak karşımıza çıkmaktadır (Deloitte-Türkiye, 2020):

- Algoritmalar: Çin' de kullanılan algoritmaların koronavirüsün (n-CoV 19) RNA ikincil yapısını tahmin etmeyi çok hızlı hale getirdiği ve pozitif olduğu düşünülen vakaların genetik analizinin yapılmasında ve virüsün mutasyonlarını doğru olarak tespit etmede kullanıldığı,

- Blockchain: Lianfei Technology, ilk blockchain salgın izleme platformu ile Çin'in her yerinden verilerin gerçek zamanlı takip edilmesini ve verilen bilgilerin açı, şeffaf ve izlenebilir olması ile birlikte yanlış bilgilerin minimize edilmesini sağladığı,

- Bulut Bilişim: Alibaba Cloud tarafından The Jack Ma Vakfı ile ortaklaşa geliştirilen COVID19'la Mücadele için Global MediXchange (GMCC) programıla bulut bilişim teknolojisini kullanarak pandemi ile ilgili deneyimlerin diğer tıbbi ekiplerle paylaşılmasının sağlandığı,

- Akıllı Ses Tarama Sistemi: 3 bin adet yapay zeka robotu ile gerçekleştirilen akıllı ses taraması sayesinde 580 bin adet ses taraması ve bin 600'den fazla şüpheli vakayı tespitinin sağlandığı,

- Akıllı Görüntü Okuma Sistemi: Radyologların yetersiz kalması durumunda kullanılan bin 500 'ün üzerinde sağlık kuruluşunda 5 bin civarında hastanın görüntülerinin okunarak yorumlamasının sağlandığı,

- 5G Teknolojisi: 5G teknolojisinin kullanılarak hastalar ile uzaktan görüşmelerin sağlandığı ve Pekin'de yapılan Huoshenshan Hastanesinin şantiye görüntülerinin 24 saat boyunca tüm dünya ile paylaşılmasının sağlandığı,

- 5G Devriye Robotları: Guangzhou Gosuncn Robotics tarafından geliştirilen 5G devriye robotları ile vücut sıcaklıklarının temas olmadan ölçülebilmesinin sağlandığı,

- Drone Teknolojisi: Vatandaşların bu drone'lar aracılığı ile maske konusunda uyarılmasının sağlandığı,

- Akıllı Uygulamalar: Takip haritalarının hazırlanmasının, yayılmanın önlenmesinde WeChat ve Alipay uygulamalarının kullanılarak sağlandığı,

- Uzaktan Eğitim/Çalışma: 300 katılımcıya kadar Tencent Meeting ve WeChat Work uygulamasıyla sesli ve görüntülü konferasların yapılmasının ve "Çevrimiçi Sınıf" uygulamaları ile öğrencilerin uzaktan erişim ile ders yapabilmesinin sağlandığı iletilmektedir.

\section{SONUÇ}

COVID-19 pandemisi tüm dünyayı derinden etkilerken olayın ilk başladığı yer olan Çin'de normalleşme süreci devam etmektedir. Henüz ikinci bir dalganın yaşanıp yaşanmayacağı, tedavi ve/veya aşının bulunup bulunmayacağı kesinleşmiş değildir. Dolayısıyla hem Çin hem de küresel olarak diğger ülkelerde pandemi ile mücadele devam etmektedir. Bu süreçte zaten devam etmekte olan dijitalleşme süreci de fiziksel olarak bir araya gelmenin mümkün 
olmadığı günlerde daha zorunlu hale gelmiş ve hız kazanarak pek çok yatırımın yapılmasını gerektirmiştir. Dijitalleşme denince enformasyon teknolojilerinin kullanımı konusu karşımıza çıkmaktadır. Enformasyon teknolojileri bilginin elde edilmesinde insanlık tarihinde çok uzun zamandır kullanılmaktadır. Ancak hiçbir dönem bugünkü kadar büyük bir miktarda bu teknolojiler çeşitlenmemiş ve gelişmemiştir. Enformasyon teknolojileri alanında yaşanan gelişmeler hayatlarımızı büyük ölçüde kolaylaştırıken pek çok iş sürecini de hız, zaman ve mekan bağlamında olumlu yönde etkileyebilmektedir. Dolayısıyla özellikle pandemi sürecini yaşadığımız bugünlerde daha çok ihtiyaç duyulan şeyin enformasyon teknolojileri olması kaçınılmaz olmaktadır.

Enformasyon teknolojileri pandemi ile savaşta dünya genelinde ve ülkemizde çokça kullanılmaktadır. Özellikle Çin özelinde sahip olunan teknolojiler bir araya getirilerek pandemi ile mücadelede aktif bir rol oynaması sağlanmıştır. Yapay zeka ile algoritmaların tahminleme aracı olarak kullanılarak analizlerin yapılması, 5G teknolojisinin kullanılarak doktor-hasta, doktor-doktor gibi sağlık iletişiminde önemli rol üstlenen bireylerin etkileşimde olmasının sağlanması, vücut ısılarının robotlar aracılığı ile taranarak saptanması, akıllı uygulamalarla takip haritalarının oluşturulması ve uzaktan erişimin sağlanarak çalışma ve eğitim hayatının sürdürülmesi gibi çabaların tümü COVID-19 ile mücadelede enformasyon teknolojilerinin Çin' de etkili bir şekilde kullanıldığını ve büyük öneme sahip olduğunu ortaya koymaktadır. Çin'de kat edilen ilerleme diğer ülkelerin de dikkatini çekerek benzer uygulamaların kullanıldığı da bilinmektedir. 


\section{TEŞEKKÜR}

Bu çalışma vesilesi ile tüm sağlık çalışanlarına, pandeminin sona ermesi için çaba sarf etmekte olan tüm emek sahiplerine teşekkürü bir borç biliriz.

\section{KAYNAKÇA}

AA. (2020, Şubat 3). Çin'in koronavirüs nedeniyle 10 günde inşa ettiği hastane açıldı. aa.com.tr: https://www.aa.com.tr/tr/dunya/cinin-koronavirus-nedeniyle-10-gunde-insa-ettigi-hastaneacildi/1722658

AA. (2020, Mart 11). Sağlık Bakanı Koca Türkiye'de ilk koronavirüs vakasının görüldüğünü açıkladı. AA.com.tr: $\quad$ https://www.aa.com.tr/tr/koronavirus/saglik-bakani-koca-turkiyede-ilkkoronavirus-vakasinin-goruldugunu-acikladi/1761466

AA. (2020, Mart 5). Salgın Çin'de hız kesti, yüzleşme sırası dünyada. aa.com.tr: https://www.aa.com.tr/tr/analiz/salgin-cinde-hiz-kesti-yuzlesme-sirasi-dunyada-/1755764

Acar, G. (2008). Enformasyon Sistemlerin Stratejik Önemi ve Planlaması. Yönetim Bilimleri Dergisi, 6(1), 53-75.

Ackoff, R. L. (1996, Ağustos 10). On Learning and Systems That Facilitate It. CQM Journal, 5(2). Center for Quality of Management Journal: https://web.archive.org/web/20070814015549/http://cqmextra.cqm.org/cqmjournal.nsf/reprints/r p07300

Akgün, A. E., \& Keskin, H. (2003). Sosyal Bir Etkileşim Aracı Olarak Bilgi Yönetimi ve Bilgi Yönetimi Süreci. Gazi Üniversitesi İktisadi ve İdari Bilimler Fakültesi Dergisi, 1, 175-188.

Akıncı-Vural, B. (2005). Enformasyon İletişim Teknolojileri: Gelişimi, Doğası ve Ahlaki Konular. Yeni Düşünceler, 1(1), 125-136.

Alba, E., Dorronsoro, B., (2005). The Exploration/Exploitation Tradeoff in Dynamic Cellular Genetic Algorithms. IEEE, Transactions on Evolutionary Computation, 9, 26-142.

Altınel, İ.K., Öncan, T., (2005). A New Enhancement of the Clarke and Wright Savings Heuristic for the Capacitated Vehicle Routing Problem. Journal of the Operational Research Society, 56 (8), 954-961.

Aydın, A. F. (2020). Post-Truth Dönemde Sosyal Medyada Dezenformasyon: Covid-19 (Yeni Koronavirüs) Pandemi Süreci. Asya Studies-Academic Social Studies/Akademik Sosyal Araştırmalar, 4(12), 76-90.

Davenport, T. H., \& Prusak., L. (2001). İş Dünyasında Bilgi Yönetimi: Kuruluşlar Ellerindeki Bilgiyi Nasıl Yönetirler. (G. Günay, Çev.) İstanbul: Rota Yayınları.

Deloitte-Türkiye. (2020). Yeni Nesil Teknolojilerin COVID-19 Mücadelesindeki Önemi-Ülke Örnekleri. Deloitte Touche Tohmatsu Limited-Türkiye. https://www2.deloitte.com/content/dam/Deloitte/tr/Documents/consulting/yeni-nesilteknolojilerin-covid-19-mucadelesindeki-onemi.pdf 
Dervişoğlu, H. (2004). Stratejik Bilgi Yönetimi. İstanbul: Dışbank Yayınları.

Develi, H. (2020, Temmuz 16). Yeni normalde dijitalleşme süreci. dunya.com: https://www.dunya.com/kose-yazisi/yeni-normalde-dijitallesme-sureci/475258

Duarte, F. (2020, Nisan 29). İspanyol Gribi: 50 milyon insanı öldüren salgın bittiğinde dünya ne haldeydi? bbc.com/turkce: https://www.bbc.com/turkce/haberler-dunya-52473039

Goldberg, D., (1989). Genetic Algorithms in Search, Optimization and Machine Learning. Reading, Boston: MA: Addison-Wesley Professional.

Hinton, T.G., (2010). The Vehicle Routing Problem including a range of Novel Techniques for its Solution. Yayınlanmamış Doktora Tezi. Bristol Üniversitesi, İngiltere.

Jaszkiewicz, A., Ishibuchi, H., Zhang, Q., (2012). Multiobjective Memetic Algorithms. F. Neri, C. Cotta, P. Moscato (Edt.), Handbook of Memetic Algorithms, içinde (s. 201-217). Berlin: Springer-Verlag, Berlin Heidelberg.

İpe, M. (2003). Knowledge Sharing in Organizations: A Conceptual Framework. Human Research Development Review, 2(4), 337-359.

Kalseth, K., \& Cummings, S. (2001). Knowledge Management: Development Strategy or Business Strategy? Information Developlemt, 17(3), 163-172.

Kişin, B. (2020, Mayıs 7). Koronavirüs sonrası tüketimde hangi trendler bizleri bekliyor? marketingturkiye.com.tr: https://www.marketingturkiye.com.tr/haberler/koronavirus-sonrasituketimde-hangi-trendler-bizleri-bekliyor/

Pemberton, M. J. (1998). Knowledge Management (KM) and The Epistemic Tradition. Records Management Quarterly, 32(3), 58-62.

Sağlık-Bakanlığı. (2020, Ağustos 20). COVID-19 (Yeni Koronavirüs Hastalı̆̆ı) Nedir? covid19bilgi.saglik.gov.tr: https:/covid19bilgi.saglik.gov.tr/tr/covid-19-yeni-koronavirushastaligi-nedir.html

Stewart, T. A. (1997). Intellectual Capital: The New Wealth of Organizations. New York: Doubleday Currency.

Süleymanlı, E. (2020, Ağustos 10). Pandemi Sonrası Süreçte Alışkanlıklarımız Değişecek. e-koronafobi: https://npistanbul.com/koronavirus/pandemi-sonrasi-surecte-aliskanliklarimiz-degisecek

Türk-Eczacıları-Birliği. (2020, Ağustos 20). Coronavirüs Hakkında Bilinmesi Gerekenler. teb.org.tr: https://www.teb.org.tr/uploads/brosur/corona.pdf

Ural, Ş. (2012). Enformasyon Kavramı Üzerine. Türk Kütüphaneciliği, 26(3), 536-547.

WHO. (2020, Ağustos 28). WHO Coronavirus Disease (COVID-19) Dashboard. covid19.who.int: https://covid19.who.int/?gclid=Cj0KCQjw1qL6BRCmARIsADV9JtafdA8hbTI15Eb8OpnG8XED5 HBQh0xh1FHdIYdaLpjZ1T3KMIiq88waAjbsEALw_wcB 
Worldometer. (2020, Ağustos 28). World/Countries/China. worldometers.info: https://www.worldometers.info/coronavirus/country/china/

Yalçın, N. (2017). Enformasyon Toplumu Bağlamında Teknolojik Distopya Üzerine Bir Çalışma: Mr. Robot Örneği. e-Journal of New Media/Yeni Medya Elektronik Dergi-eJNM, 1(1), 93-101.

Zhang, H., Liu, B., (2009). A New Genetic Algorithm for Order-Picking of Irregular Warehouse. International Conference on Environmental Science and Information Application Technology, 1, 121-124. 